\title{
Article
}

\section{TP53 Abnormalities and MMR Preservation in 5 Cases of Proliferating Trichilemmal Tumours}

\author{
Raquel Martín-Sanz ${ }^{1}$, José María Sayagués ${ }^{2} \oplus$, Pilar García-Cano ${ }^{3}$, Mikel Azcue-Mayorga ${ }^{4}$, \\ María del Carmen Parra-Pérez ${ }^{2}$, María Ángeles Pacios-Pacios ${ }^{2}$, Enric Piqué-Durán ${ }^{5, *(\mathbb{D})}$ and Jorge Feito ${ }^{2,6, * \mathbb{D}}$ \\ 1 Ophthalmology Department, Complejo Asistencial Universitario de Salamanca, 37007 Salamanca, Spain; \\ rmartinsan@saludcastillayleon.es \\ 2 Pathology Department, Complejo Asistencial Universitario de Salamanca, 37007 Salamanca, Spain; \\ ppmari@usal.es (J.M.S.); mcparra@saludcastillayleon.es (M.d.C.P.-P.); \\ mapacios@saludcastillayleon.es (M.Á.P.-P.) \\ 3 Plastic Surgery Department, Complejo Asistencial Universitario de Salamanca, 37007 Salamanca, Spain; \\ pgarciac@saludcastillayleon.es \\ 4 Pathology Department, Hospital José Molina Orosa, 35500 Arrecife, Spain; mazcmay@gobiernodecanarias.org \\ 5 Dermatology Department, Hospital José Molina Orosa, 35500 Arrecife, Spain \\ 6 Human Anatomy and Histology Department, Universidad de Salamanca, 37007 Salamanca, Spain \\ * Correspondence: enric@aedv.es (E.P.-D.); jfeito@saludcastillayleon.es (J.F.)
}

\section{check for} updates

Citation: Martín-Sanz, R.; Sayagués, J.M.; García-Cano, P.; Azcue-Mayorga, M.; Parra-Pérez, M.d.C.;

Pacios-Pacios, M.Á.; Piqué-Durán, E.; Feito, J. TP53 Abnormalities and MMR Preservation in 5 Cases of Proliferating Trichilemmal Tumours. Dermatopathology 2021, 8, 147-158. https://doi.org/10.3390/

dermatopathology 8020021

Academic Editor: Gürkan Kaya

Received: 1 March 2021

Accepted: 22 May 2021

Published: 25 May 2021

Publisher's Note: MDPI stays neutral with regard to jurisdictional claims in published maps and institutional affiliations.

Copyright: (c) 2021 by the authors. Licensee MDPI, Basel, Switzerland. This article is an open access article distributed under the terms and conditions of the Creative Commons Attribution (CC BY) license (https:/ / creativecommons.org/licenses/by/ $4.0 /)$.

\begin{abstract}
Proliferating trichilemmal tumours (PTT) are defined by a benign squamous cell proliferation inside a trichilemmal cystic (TC) cavity. A possible explanation of this proliferative phenomenon within the cyst may be molecular alterations in genes associated to cell proliferation, which can be induced by ultraviolet radiation. Among other genes, alterations on TP53 and DNA mismatch repair proteins (MMR) may be involved in the cellular proliferation observed in PTT. Based on this assumption, but also taking into account the close relationship between the sebaceous ducts and the external root sheath where TC develop, a MMR, a p53 expression assessment and a TP53 study were performed in a series of 5 PTT cases, including a giant one. We failed to demonstrate a MMR disorder on studied PTT, but we agree with previous results suggesting increased p53 expression in these tumours, particularly in proliferative areas. TP53 alteration was confirmed with FISH technique, demonstrating TP53 deletion in most cells.
\end{abstract}

Keywords: trichilemmal cyst; proliferating trichilemmal tumor; MMR; TP53; p53

\section{Introduction}

Trichilemmal cyst (TC) is a benign cyst derived from the external root sheath of the catagen hair follicle isthmus by a budding-off mechanism [1]. TCs are generally located on the scalp and have a slight predilection for females $[2,3]$.

Proliferating trichiilemmal tumour (PTT) was described in 1966, accounting for $2 \%$ of the TC, and has been initially considered a variant of these trichilemmal cysts [4,5]. This tumour has been described under different denominations, but PTT is the currently accepted term $[4,6]$. PTTs are defined histologically by an endophytic proliferation, sometimes with a lobulated pattern, giving a multiloculated or solid aspect [4]. They have a homogenous keratinization, lacking a defined granular layer, similar to TCs. Calcification is a common finding [4,7]. As the TCs, the PTTs are usually located in the scalp, have slight predilection for females and have a variable size, ranging from very small lesions to giant tumours [4]. Although they were proposed to develop from TC [4], recent studies propose a de novo genesis [8].

Aggressive, malignant or even metastasizing variants of PTT have been described [7,9,10]. Malignant degeneration can be present over a preexisting PTT [11,12], involving an infiltrating pattern with variable cytological atypia $[9,13]$. Malignant cases may have differential diagnosis issues regarding either keratinizing squamous cell carcinoma or trichilemmal 
carcinoma $[9,14,15]$. The cytokeratin immunohistochemical (IHQ) pattern is not helpful in distinguishing these entities [16]. However, Ki67 has demonstrated an intermediate proliferation rate in PTT, in a range between squamous carcinoma and TC, suggesting PTT is not a trivial cyst. It is, instead, a low-grade neoplasm with a potentially aggressive clinical course [6,17-19]. Ki67, altogether with CD34 and p53, may aid in differentiating PTT from squamous cell carcinoma [14].

Regarding the molecular mechanisms responsible for developing these cystic lesions, genetic susceptibility was described for simple TC in some cases: hereditary cases may develop with an autosomal dominant type of transmission, involving incomplete penetrance $[1,20,21]$. TC development has been recently related with phospholipase $C$ delta 1 (PLCD1), probably via an inherited PLCD1 high-risk allele and somatic spontaneous mutation on the other allele [20,21]. Very little mutation analysis has been performed on PTTs: there were described genetic anomalies, mainly aneuploidy, within some PTT [17]. Mutations were noted on locus 17p13, where TP53 gene resides [18,19]. Some reports had related these genetic alterations with malignant change [22,23], associated occasionally with TP53 deletion [12]. The precise mechanism responsible of the proliferative ability of PTT has been not yet clarified, but the accumulation of mutations on tumour suppressor genes seems a possible option [20].

Mismatch repair (MMR) is one of the cellular mechanisms involved in the repair of DNA injuries, caused by insertions or deletions produced during DNA replication by DNA polymerases [24]. A mutation on these genes is constitutively present in the cells of Lynch syndrome patients, and also in its variant associated with cutaneous sebaceous neoplasms, Muir-Torre syndrome $[25,26]$. This mutation is also present in other carcinomas including up to $15 \%$ of sporadic colorectal adenocarcinomas $[24,27]$. MMR can be routinely diagnosed by IHQ targeted against the key proteins MSH2, MSH6, MLH1 and PMS2, or directly by testing microsatellite instability (MSI): both techniques have high sensitivity in detecting both Lynch syndrome and the sporadic forms of MSI [28]. Our lab employs MMR IHQ as long as morphology is preserved on the slide.

Regarding skin tumours, the significant relationship between sebaceous tumours and Muir-Torre syndrome makes neccesary to look for abnormalities regarding MMR expression when diagnosing these tumours [29,30], although MMR abnormalities per se do not permit the distinction between Muir-Torre associated and sporadic sebaceous tumours [31]. Keratoacanthomas are also associated with Muir-Torre syndrome [26]; these tumours are more frequent and usually do not demonstrate MMR alterations when studied in the general population [32]. However, in patients with Muir-Torre syndrome, a MMR alteration can be found in keratoacanthomas, and also in other premalingnant lesions such as actinic keratosis (AK) or Bowen's disease [33]. Other cutaneous tumours where the role of MMR proteins has been studied are melanocytic tumours [34], squamous neoplasms [35] and even simple TC [36], showing reduced expression in melanocytic lesions and no evidence of mutation in squamous carcinoma or trichilemmal cysts. MMR positive neoplasms are a promising target of immunotherapy in the future [37].

Ultraviolet (UV) ratiation, in particular UVB, is responsible of cutaneous neoplasms development, via direct DNA damage [38]. TP53 has been particularly linked with UV damage, and there are 'signature' TP53 mutations in skin cells and tumours that are highly associated with UV damage [38,39]. MMR, the other studied repair mechanism has a less evident relationship with UV, but there is indirect evidence supporting its role in UV repairment [38]. However, although its mutation is likely to contribute to squamous cell carcinoma (SCC) progression, MMR deficiency is unlikely to play a significant role in SCC carcinogenesis [40].

The usual location of PTT is the scalp [11], although PTT is an odd lesion that has been described in unsuspected areas, like glabrous skin (i.e., skin devoid of terminal hair follicles) [41] or other regions distant from the head [42]. In the usual scalp location these tumours can reach giant dimensions [42-47]. The preference for a cephalic location suggests a possible role of UV in the development of trichilemmal lesions. 
Finally, although PTT is not a sebaceous lesion, they have a common embriologic origin and hair follicle anatomy indicates that the isthmus region where TC and PTT develop is closely related to the sebaceous gland [48]. On one hand, the sebaceous gland may be the target to obtain hair follicle stem cells from the isthmus and bulge [49]. On the other hand, bulge cells can be mobilised to maintain sebaceous glands [48], crossing the isthmus for this purpose [2]. Besides, there are reports of PTT with divergent differentiations, including sebaceous [50] or apocrine [50,51]. Furthermore, there are also examples of association between sebaceous carcinoma and PTT, with no clinical evidence of Muir-Torre or Lynch syndrome [52]. Based on these assumptions, we wanted to search for alterations in the IHQ expression of p53 and MMR proteins, also looking for deletion of TP53 in these tumours via a FISH assay, in an attempt to explain their proliferating nature.

\section{Materials and Methods}

A series of five PTT cases diagnosed in the last 6 years were included in the study, with cases from José Molina Orosa Hospital $(n=4)$ and a giant case from Complejo Asistencial Universitario de Salamanca $(\mathrm{n}=1)$, (Table 1$)$.

Table 1. Cases included in the study.

\begin{tabular}{ccccc}
\hline Case & Gender & Age & Topography & Size \\
\hline Case 1 & Female & 88 & Scalp (occipital) & $9 \mathrm{~cm}$ \\
Case 2 & Female & 45 & Back & $1 \mathrm{~cm}$ \\
Case 3 & Female & 84 & Scalp (frontal) & $3 \mathrm{~cm}$ \\
Case 4 & Female & 63 & Scalp (occipital) & $3 \mathrm{~cm}$ \\
Case 5 & Female & 69 & Scalp (parietal) & $1.5 \mathrm{~cm}$ \\
\hline
\end{tabular}

Most patients had non ulcerated multilobed masses that were resected with clinical suspect of trichilemmal cyst (Figure 1a). On occasion a dilated pore was present, guiding the diagnosis (Figure 1b). The exception is Case 2, where fibroma or Pinkus fibroepitelioma were the clinical diagnoses (Figure 1c). None of the studied cases had cutaneous malignant events and no posterior recurrence was found (with at least 1 year follow-up).
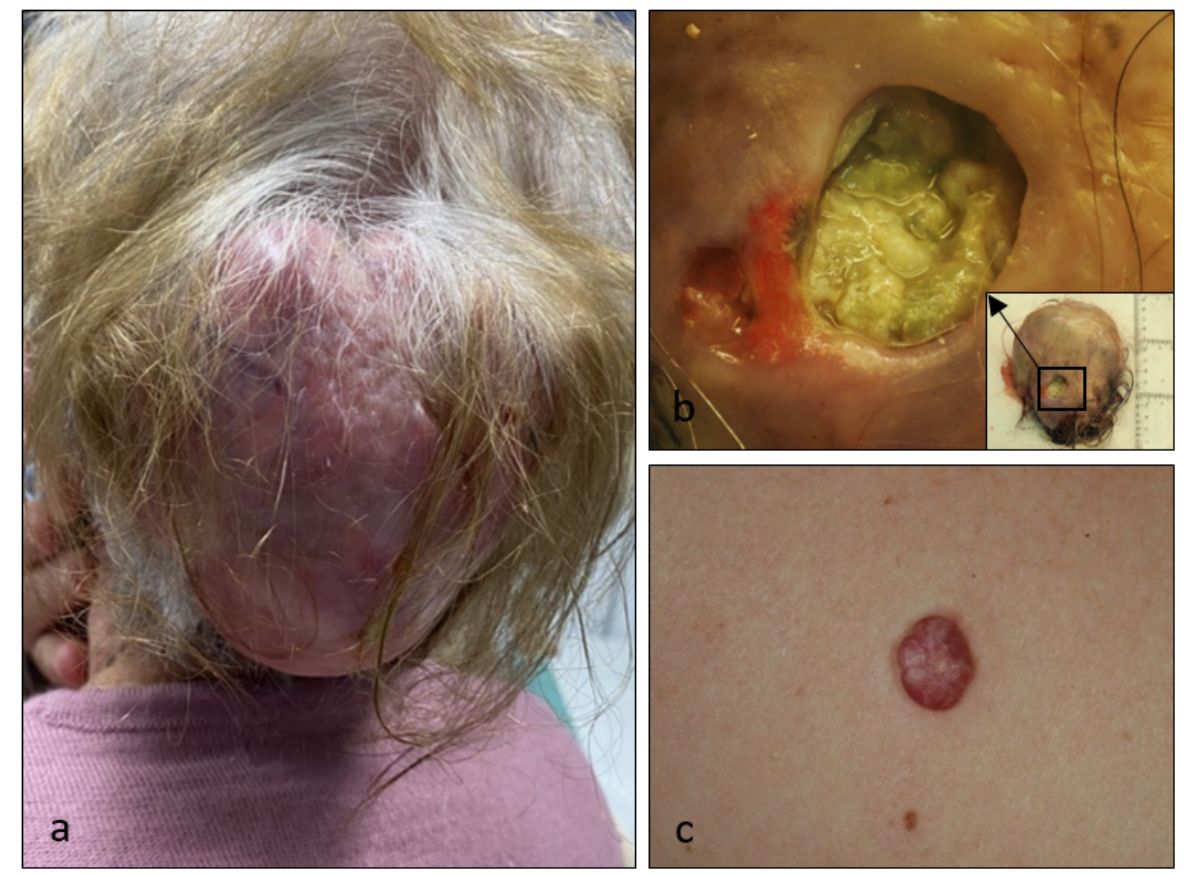

Figure 1. Clinical and macroscopic images of proliferating trichilemmal tumours. There is depicted Case 1 before the surgical procedure (a) and in the pathology laboratory, before fixation, where a dilated pore was prominent (b). There is also depicted Case 2 in the back (c). 
Samples were routinely embedded in paraffin for light microscopy. Paraffin blocks were cut into $3 \mu \mathrm{m}$ sections and stained with haematoxilyn-eosin. IHQ was performed in a Bond III platform (Leica, Wetzlar, Germany) using prediluted antibodies from Leica Biosystems, directed against p53 (clone DO-7, Leica Biosystems, prediluted), MSH2 (code PA0989, clone 79H11), MSH6 (code PA0990, clone EP49), MLH1 (code PA0988, clone ES05) and PMS2 (code PA0991, clone EP51). Images were taken with an Olympus BX53 microscope connected to an Olympus UC90 camera (Olympus, Tokyo, Japan), with no ulterior image proccessing. After conventional histological studies, a copy number alterations TP53 study was performed using fluorescence in situ hybridization (FISH), with a probe specific for the TP53 gene located in chromosome 17p13 and another directed to the centromere of chromosome 17 (17p11.1) (Vysis, Downers Grove, IL, USA). The number of hybridization spots was evaluated using a DMRB fluorescence microscope (Leitz, Wetzlar, Germany) equipped with a $100 \times$ oil objective, which was used for counting the number of hybridization spots/cell in at least 200 cells/sample.

\section{Results}

The studied tumours showed a well-defined cystic architecture, with several proliferative changes and a trichilemmal squamous lining (Figure 2). Detailed examination of the epithelium demonstrated no pleomorphism, although occasional reactive features may be noted in the more solid regions (Figure $2 \mathrm{~h}$ ).

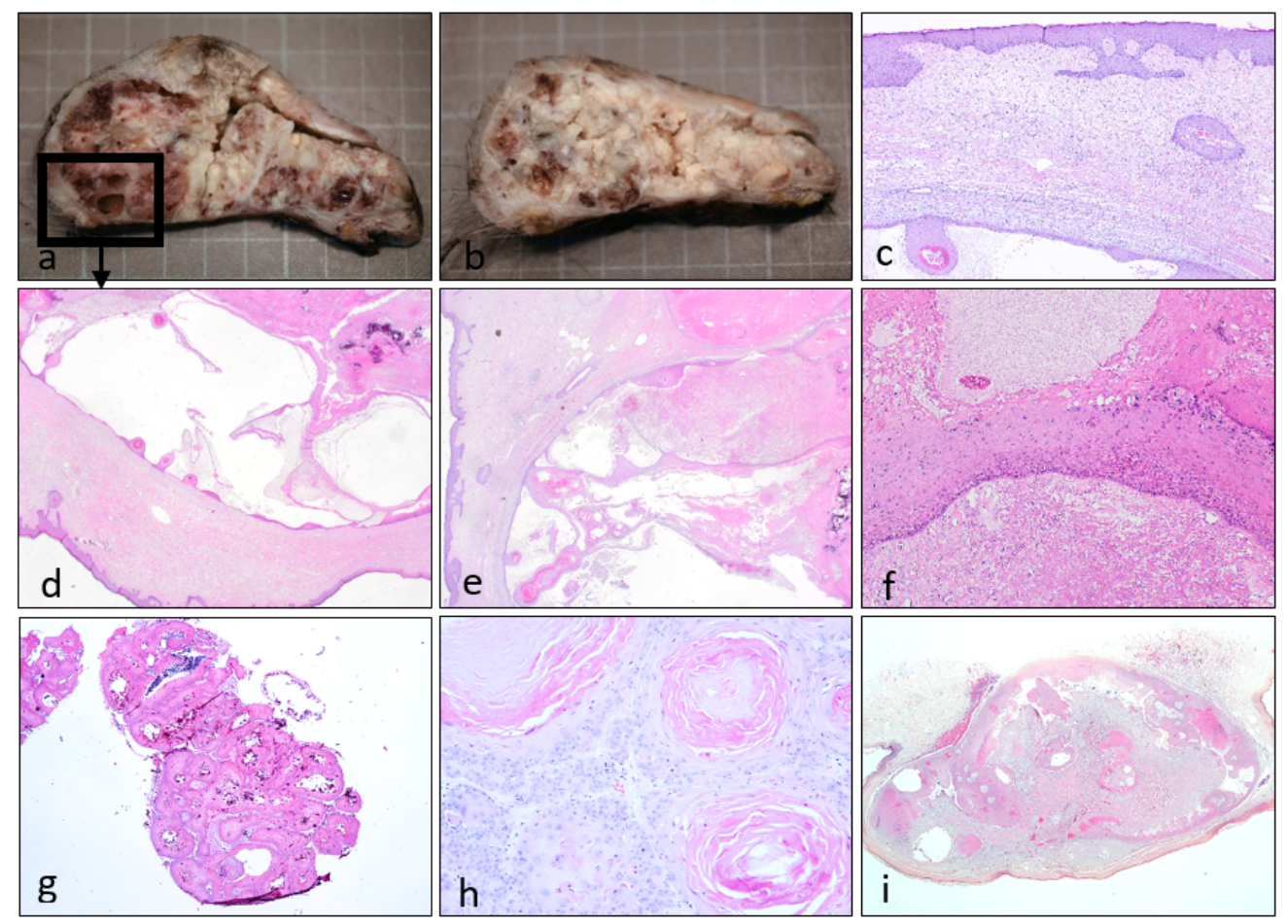

Figure 2. Correlation between macroscopic aspect after fixation and histological images. On the giant lesion (Case 1, a-f) was appreciable the multiloculated aspect, alternating whitish keratotic content and more solid lesions (a,b). Histologically the lesion presented a hyperplastic epidermis and an underlying cystic lesion with epithelial endophytic projections and anastomosing epithelial strands (b-e); image " $\mathrm{d}$ " corresponds to the macroscopic lesion marked in image "a". On some areas trichilemmal epithelium (left side) presented focally a prominent granular layer (right side), with compact keratinization and parakeratosis (f). Histologic findings were variable, with marked calcification and minor keratin content (Case 5, g). In the solid areas maturation was preserved, with reactive changes and minor inflammation (Case 3, h). Tumoral silhouette generally revealed a sharply defined cystic lesion, with proliferation towards the interior of the cyst (Case 2, i). 
The four MMR proteins (MSH2, MSH6, MLH1, and PMS2) were expressed in all the studied tumours, in both tumour epithelium and normal covering skin (Figure 3a-d). Most cells demonstrated nuclear expression of the four MMR proteins in the epidermis and also in the hair follicles (Figure $3 \mathrm{e}-\mathrm{h}$ ); this expression was especially evident on epidermal basal and squamous layers, declining in the granular layer. The proliferative cystic epithelium had regions with sparser expression than epidermis (Figure 3i-1) while other more cellular areas demonstrated widespread positivity (Figure $3 \mathrm{~m}-\mathrm{p}$ ). Results are semiquantitatively summarized in Table 2.

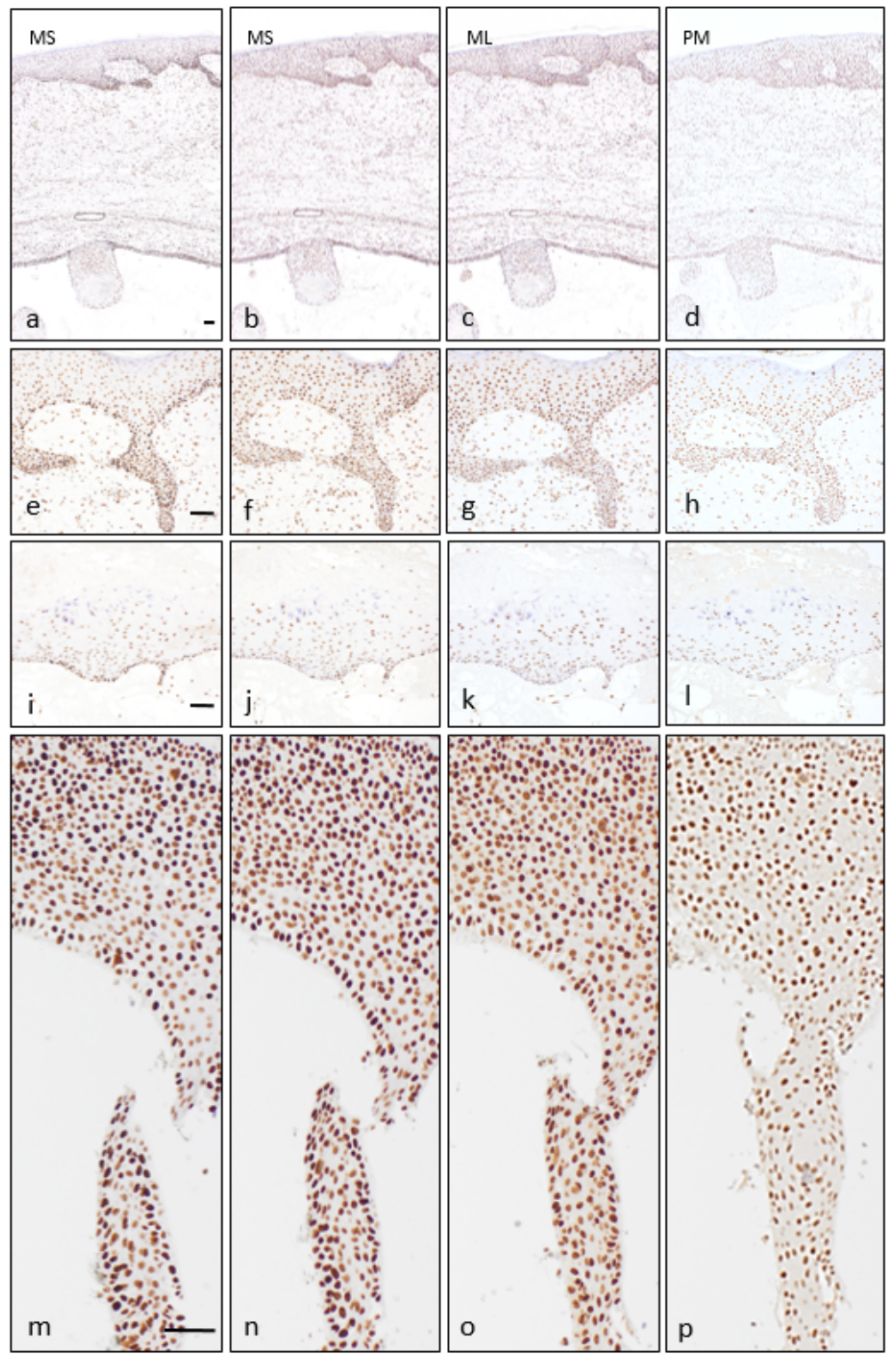

Figure 3. Mismatch repair protein expression. There are depicted immunohistochemical results for MSH6 (a,e,i, m), MSH2 (b,f,j,, $\mathbf{n})$, MLH1 $(\mathbf{c}, \mathbf{g}, \mathbf{k}, \mathbf{o})$ and PMS2 $(\mathbf{c}, \mathbf{h}, \mathbf{l}, \mathbf{p})$ in different regions of Case 1 to illustrate their variability. Tumour can be identified in the inferior part of the image, with slightly hyperplastic overlying skin (a-d). On a detailed view, overlying skin displayed widespread nuclear expression with positive control in dermal inflammatory cells $(\mathbf{e}-\mathbf{h})$. On the tumour there were present areas with reduced nuclear expression in the thinnest epithelial lining with focal hypergranulosis (i-1), contrasting with the increased expression in proliferative areas $(\mathbf{m}-\mathbf{p})$. Scale bars $(\mathbf{a}-\mathbf{d}, \mathbf{e}-\mathbf{1}, \mathbf{m}-\mathbf{p}): 50 \mu \mathrm{m}$. 
Table 2. Immunohistochemical results of MMR, p53 immunohistochemistry (IHQ) and TP53 deletion in fluorescence in situ hybridization (FISH).

\begin{tabular}{ccccccc}
\hline Case & MSH2 & MSH6 & MLH1 & PMS2 & P53 IHQ & TP53 Loss \\
\hline Case 1 & $80 \%$ & $80 \%$ & $60 \%$ & $70 \%$ & Weak & $63 \%$ \\
Case 2 & $60 \%$ & $60 \%$ & $40 \%$ & $30 \%$ & Negative & $65 \%$ \\
Case 3 & $90 \%$ & $80 \%$ & $80 \%$ & $80 \%$ & Negative & $52 \%$ \\
Case 4 & $90 \%$ & $90 \%$ & $90 \%$ & $90 \%$ & Weak & $80 \%$ \\
Case 5 & $90 \%$ & $90 \%$ & $80 \%$ & $70 \%$ & Negative & $0 \%$ \\
\hline
\end{tabular}

IHQ for p53 showed nuclear expression on many tumoral cells (Figure 4a), while overlying skin had no expression or was expressed by fewer cells (Figure 4b). It was apparent in a greater amount in the more cellular areas (Figure 4c-d). On the other hand, p53 exhibited decreased immunostaining in areas of parakeratosis, contrasting with the increased expression where trichilemmal keratinisation occurred (Figure 4e-f). Even when observing the less cellular areas, proliferative tumour had a higher degree of p53 expression than overlying skin.
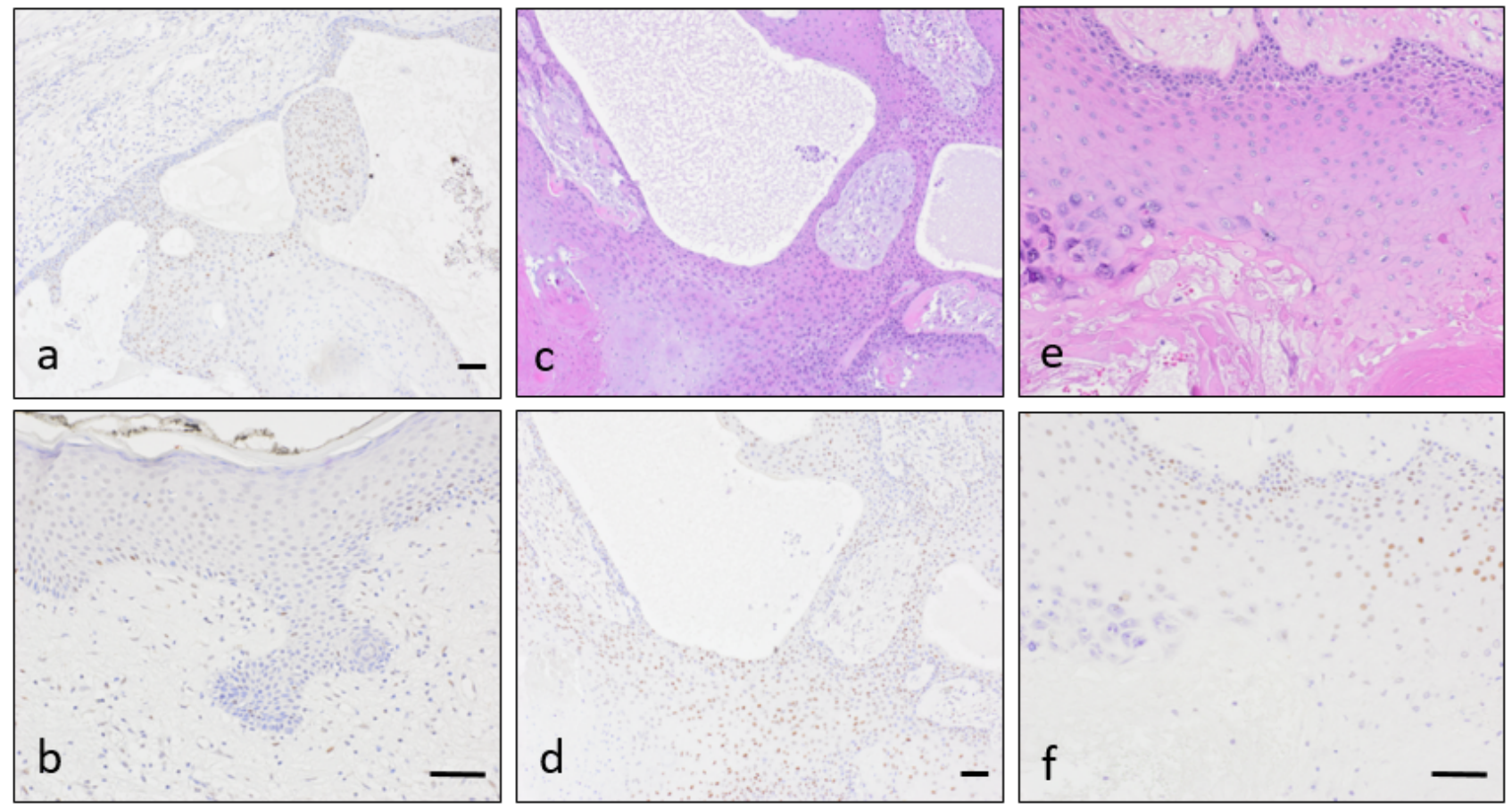

Figure 4. p53 expression on Case 1, illustrating its variability. There was weak nuclear p53 expression in the more cellular areas of the proliferating tumor (a), while in the overlying epidermis there was very scarce nuclear expression (b). There were regional differences regarding p53 expression pattern, being more obvious in the more solid and cellular regions $(\mathbf{c}, \mathbf{d})$ and less apparent when the epithelial lining was thinner or hypergranulotic $(\mathbf{e}, \mathbf{f})$. Scale bars $(\mathbf{a}, \mathbf{c}, \mathbf{d} ; \mathbf{b}, \mathbf{e}, \mathbf{f}): 50 \mu \mathrm{m}$.

$17 \mathrm{p} 13$ deletions were displayed by 4 of the 5 PTT patients included in the current study in $>50 \%$ of the studied nuclei per case (Figure 5). The remaining patient (Case 5) showed two copies of chromosome 17p13 per nuclei. 


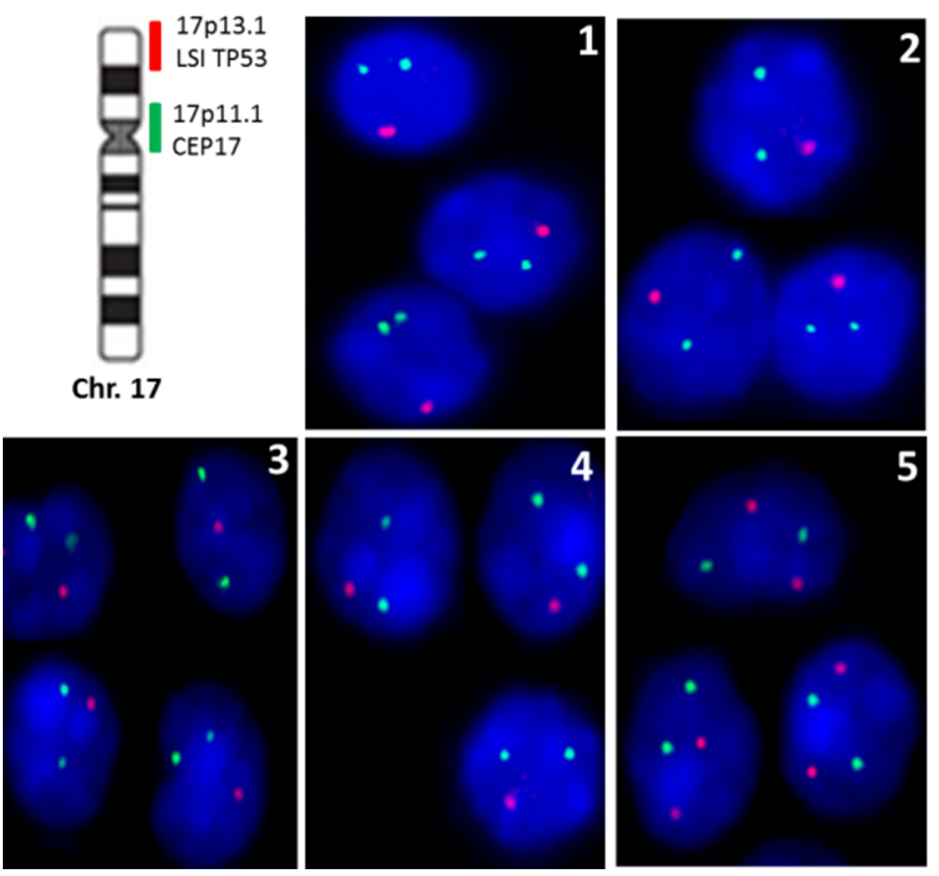

Figure 5. Representative pictures of cell nuclei from 5 PTT patients after hybridization with two probes for chromosome 17 (17p11.1 and 17p13; green and red signals, respectively). Four tumors showed loss of TP53 gene (Cases 1-4). Case 5 displayed a normal diploid number of hybridization signals for the both probes analyzed.

\section{Discussion}

UVB radiation is the main carcinogenic agent in the epidermis, being able to cause various mutations regarding both TP53 gene and also in MMR, originating MSI [38,39]. MMR and TP53 disarrangements have already been described in lung carcinogenesis [53] and their mutation have summatory effects reducing chemotherapy effect on colonic adenocarcinoma [54]. In normal skin the most important protein concerning UV-induced tumorigenesis is p53 [38], and the relevance of the MMR system remains unclear [39].

The studied tumours present areas of both increased and decreased MMR expression compared with normal epidermis of the scalp. Increased expression is morphologically related with the most proliferative regions of the tumor and decreased expression is observed usually in thin epithelial strands. We consider the result is not enough relevant, as long as intense nuclear expression of the MMR proteins can be observed in most epithelia and no homogeneous pattern of expression could be identified. In any case, the high expression in the most cellular (and probably proliferative) regions compared with the not-so-cellular areas may be the expected result, considering the previously reported overexpression in other squamous premalignant lesions [55,56].

MMR system is also likely to be a component in UVB-induced DNA damage repairment, and over-expression has been observed on occasion in SCC [57], although others failed to demonstrate a significant relationship [40]. MSH2, one of the principal components of the MMR system, is part of the TP53 repair mechanisms [55]. MSH2 is also elevated in premalignant cutaneous neoplasms, but its increased expression in SCC is less evident [55]. Furthermore, similar findings are present in other squamous lesions like cervical intraepithelial neoplasia (CIN) and carcinoma: MMR are elevated in preinvasive lesions, but they are not increased in malignant neoplasms [56]. This finding seems biologically rational, involving a higher rate of DNA repairment in premalignant lesions.

Moreover, MMR alterations are typical of sebaceous neoplasms. MMR-intact sebaceous neoplasms tend to be located in the head region (where sebaceous tumours are more prevalent), while MMR-mutated ones are, by contrast, frequent outside the head [58]. This supports the idea that MMR mutation loses importance when talking about neoplasms 
of the head region, and it is a striking thinking, as long as the head region is indeed very exposed to UV at the same time the hypothesis of an UVB related disorder on MMR proteins has been already noted [55]. A recent paper by North et al., [59] explains this apparent contradiction, caused by three mutually exclusive mutations leading to sebaceous carcinoma: the first is a MMR-mutated profile and the second is a MMR-intact one, with UV damage-associated mutations, already described in the literature [58]. The third possible mutation was described as pauci-mutational and is present in some facial tumours [59]. It has been proposed to develop from sun-shielded epithelial cells [59], which are likely to correspond to Meibomian glands. This third group of mutations can explain the low incidence of MMR mutations on sebaceous tumours in the head when compared with extracephalic ones.

In our hands, p53 expression taken alone can be interpreted either as increased or within the wild-type spectrum [60]. This result might be considered in line with an increased DNA repair status in the context of a premalignant tumour. The difference between superficial epidermis and PTT is remarkable (Figure 4a,d): p53 expression is discrete in some PTTs, but skin covering the tumor shows nearly absent expression. However, the immunohistochemical result may be considered positive and suggestive of mutation in some tumour spots [61]. FISH assay demonstrates deletion of TP53 in most cells in 80\% of our small series, so the overexpression is not only reparative, but indicative of a DNA damage leading to TP53 deletion.

TP53 is one of the most widespread genetic alterations of human oncogenesis, and its mutation usually confers higher oncogenic potential and poorer prognosis to most neoplasms [62]. UV-related alterations on TP53 have been extensively described in melanoma and also in non-melanoma cutaneous cancer [38,39]. TP53 has, indeed, an initial role in cutaneous carcinogenesis in contrast to internal malignancies, where TP53 mutations develop at a later stage [63]. Mutations in the TP53 gene have been described as an early event in SCC development and, as so, are present in AK as well as in other precursor lesions [64,65]. With the help of other molecules including calcitriol, p53 enhances DNA repair in keratinocytes $[63,66]$. In normal skin p53 is barely present, but is expressed after UV irradiation, suggesting an initial p53 overexpression to overcome the UV-caused DNA damage $[65,66]$. In this line, there has already been suggested on occasion a role of p53 alterations in PTT [12,19]. Some authors [19] consider PTT as a carcinoma, due to their similar to SCC p53 profile, while others demonstrated TP53 mutation in a malignant PTT [12]. This fact could be in accordance with the premalignant nature of PTT, but in contrast to AK where mutations occur in TP53 [67], we demonstrate a TP53 deletion in several benign appearing PTT. In this context, it would be interesting to sequence TP53 searching for UVB-signature mutations in PTT, clearly linking to sunlight exposure [63].

Although as general rule TP53 deletion implies impaired p53 expression [68], the relationship between increased p53 expression and TP53 deletion has been already evaluated in esophageal squamous carcinoma, where a correlation between both was present but not complete [69]. This correlation is specially known in haematological neoplasms [70] like multiple myeloma, where hemizygous TP53 mutation is associated with increased p53 nuclear expression due to mutations in the remaining allele [71,72]. In this disease, TP53 alterations can occur in three subsets: monoallelic deletion, monoallelic mutations and biallelic inactivation, where monoallelic deletion is the only currently associated with a high risk profile [73].

A detailed genetic study was performed once on a case of malignant PTT, which demonstrated mutated TP53 in both malignant and non malignant tumours. In that case the malignant tumour also showed allelic loss on chromosome arm 17 [12]. Our case series has an example of a non-deleted case, but the other four cases demonstrate deletion, two with weak overexpression of p53 and another two with absent p53. The presence of constitutive deletion in the majority of PTT in our series supports the hypothesis of de novo generation of PTT [8]. 


\section{Conclusions}

In summary, we have found no relevant alterations in the expression of MMR proteins on the studied cases. In any case, the mismatch repair pathway is not completely understood, and there is an important subset of patients fulfilling criteria for Lynch syndrome that do not have detectable abnormalities on MMR [74]. The TP53 deletion in $80 \%$ of studied cases, with p53 overexpression, is indicative of a serious DNA damage and a potentially aggressive neoplasm. Limitations of the present study are the small number of cases studied and the absence of precise sequentiation.

Author Contributions: Conceptualization, J.F. Methodology, J.M.S., M.Á.P.-P. Investigation: J.M.S. Formal Analysis, E.P.-D., J.F. Preparation, R.M.-S. Resources, M.A.-M. and J.F. Data Curation, P.G.-C. and E.P.-D. Visualization, M.d.C.P.-P. Writing-Original Draft Preparation, R.M.-S. Writing-Review \& Editing, J.F. and E.P.-D. Validation, R.M.-S. All authors have read and agreed to the published version of the manuscript.

Funding: This research received no external funding.

Institutional Review Board Statement: The study was approved by the hospital Ethics Committee, with reference code PI 202104725.

Informed Consent Statement: Patients have granted permission for the use of the images included.

Acknowledgments: We would like to recognise José Antonio Muñoz Leon for the macroscopic photographs in Figure 2.

Conflicts of Interest: The authors declare no conflict of interest.

\section{References}

1. Pinkus, H. "Sebaceous cysts" are trichilemmal cysts. Arch. Dermatol. 1969, 99, 544-555. [CrossRef] [PubMed]

2. Kamyab, K.; Kianfar, N.; Dasdar, S.; Salehpour, Z.; Nasimi, M. Cutaneous cysts: A clinicopathologic analysis of 2438 cases. Int. J. Dermatol. 2020, 59, 457-462. [CrossRef]

3. Leppard, B.J.; Sanderson, K.; Wells, R. Hereditary trichilemmal cysts. Hereditary pilar cysts. Clin. Exp. Dermatol. 1977, 2, 23-32. [CrossRef] [PubMed]

4. Satyaprakash, A.K.; Sheehan, D.J.; Sangueza, O.P. Proliferating trichilemmal tumors: A review of the literature. Dermatol. Surg. 2007, 33, 1102-1108. [CrossRef] [PubMed]

5. Jones, E.W. Proliferating epidermoid cysts. Arch. Dermatol. 1966, 94, 11-19. [CrossRef] [PubMed]

6. Noto, G. 'Benign' proliferating trichilemmal tumour: Does it really exist? Histopathology 1999, 35, 386-387. [CrossRef]

7. Ye, J.; Nappi, O.; Swanson, P.E.; Patterson, J.W.; Wick, M.R. Proliferating pilar tumors: A clinicopathologic study of 76 cases with a proposal for definition of benign and malignant variants. Am. J. Clin. Pathol. 2004, 122, 566-574. [CrossRef]

8. Baptista, A.P.; e Silva, L.G.; Born, M.C. Proliferating trichilemmal cyst. J. Cutan. Pathol. 1983, 10, 178-187. [CrossRef]

9. Bhavya, P.M.; Letha, V.; Anilkumar, V. Malignant Proliferating Trichilemmal Tumor: A Rare Adnexal Neoplasm. Indian J. Dermatopathol. Diagn. Dermatol. 2020, 7, 40-41. [CrossRef]

10. Park, B.S.; Yang, S.G.; Cho, K.H. Malignant Proliferating Trichilemmal Tumor Showing Distant Metastases. Am. J. Dermatopathol. 1997, 19, 536-539. [CrossRef]

11. Sau, P.; Graham, J.H.; Helwig, E.B. Proliferating epithelial cysts. Clinicopathological analysis of 96 cases. J. Cutan. Pathol. 1995, 22, 394-406. [CrossRef]

12. Takata, M.; Rehman, I.; Rees, J.L. A trichilemmal carcinoma arising from a proliferating trichilemmal cyst: The loss of the wild-type 553 is a critical event in malignant transformation. Hum. Pathol. 1998, 29, 193-195. [CrossRef]

13. Singh, P.; Usman, A.; Motta, L.; Khan, I. Malignant proliferating trichilemmal tumour. BMJ Case Rep. 2018, $2018,224460$. [CrossRef] [PubMed]

14. Chaichamnan, K.; Satayasoontorn, K.; Puttanupaab, S.; Attainsee, A. Malignant proliferating trichilemmal tumors with CD34 expression. J. Med. Assoc. Thail. 2010, 93, S28-S34.

15. Vargas-Mora, P.; Orlandi, D.; Morales, C.; Araya, I. Proliferating Trichilemmal Cysts: A Clinicopathological Study of 14 Cases. Int. J. Trichol. 2019, 11, 258-259. [CrossRef]

16. Haas, N.; Audring, H.; Sterry, W. Carcinoma arising in a proliferating trichilemmal cyst expresses fetal and trichilemmal hair phenotype. Am. J. Dermatopathol. 2002, 24,340-344. [CrossRef]

17. Hashimoto, Y.; Matsuo, S.; Iizuka, H. A DNA-flow cytometric analysis of trichilemmal carcinoma, proliferating trichilemmal cyst and trichilemmal cyst. Acta Dermato-Venereol. 1994, 74, 358-360.

18. Takata, M.; Quinn, A.G.; Hashimoto, K.; Rees, J.L. Low Frequency of loss and heterozygosity at the nevoid basal cell carcinoma locus and other selected loci in appendageal tumors. J. Investig. Dermatol. 1996, 106, 1141-1144. [CrossRef] 
19. Fernández-Figueras, M.T.; Casalots, A.; Puig, L.; Llatjós, R.; Ferrándiz, C.; Ariza, A. Proliferating trichilemmal tumor: p53 immunoreactivity in association with p27Kip1 over-expression indicates a low-grade carcinoma profile. Histopathology 2001, 38, 454-457. [CrossRef] [PubMed]

20. Hörer, S.; Marrakchi, S.; Radner, F.P.; Zolles, G.; Heinz, L.; Eichmann, T.O.; Has, C.; Salavei, P.; Mahfoudh, N.; Turki, H.; et al. A Monoallelic Two-Hit Mechanism in PLCD1 Explains the Genetic Pathogenesis of Hereditary Trichilemmal Cyst Formation. J. Investig. Dermatol. 2019, 139, 2154-2163.e5. [CrossRef]

21. Kolodney, M.S.; Coman, G.C.; Smolkin, M.B.; Hagen, R.; Katzman, J.A.; Katzman, S.N.; Holliday, A.C.; Kolodney, J.A. Hereditary Trichilemmal Cysts are Caused by Two Hits to the Same Copy of the Phospholipase C Delta 1 Gene (PLCD1). Sci. Rep. 2020, 10, 6035. [CrossRef]

22. Rutty, G.; Richman, P.; Laing, J. Malignant change in trichilemmal cysts: A study of cell proliferation and DNA content. Histopathology 1992, 21, 465-468. [CrossRef] [PubMed]

23. Herrero, J.; Monteagudo, C.; Ruiz, A.; Llombart-Bosch, A. Malignant proliferating trichilemmal tumours: An histopathological and immunohistochemical study of three cases with DNA ploidy and morphometric evaluation. Histopathology 1998, 33, 542-546. [CrossRef]

24. Boland, C.R.; Thibodeau, S.N.; Hamilton, S.R.; Sidransky, D.; Eshleman, J.R.; Burt, R.W.; Meltzer, S.J.; Rodriguez-Bigas, M.A.; Fodde, R.; Ranzani, G.N.; et al. A National Cancer Institute Workshop on Microsatellite Instability for cancer detection and familial predisposition: Development of international criteria for the determination of microsatellite instability in colorectal cancer. Cancer Res. 1998, 58, 5248-5257.

25. Moreira, L.; Balaguer, F.; Lindor, N.; De La Chapelle, A.; Hampel, H.; Aaltonen, L.A.; Hopper, J.L.; Le Marchand, L.; Gallinger, S.; Newcomb, P.A.; et al. Identification of lynch syndrome among patients with colorectal cancer. JAMA 2012, 308, 1555-1565. [CrossRef] [PubMed]

26. Le, S.; Ansari, U.; Mumtaz, A.; Malik, K.; Patel, P.; Doyle, A.; Khachemoune, A. Lynch Syndrome and Muir-Torre Syndrome: An update and review on the genetics, epidemiology, and management of two related disorders. Dermatol. Online J. 2017, $23,13030$. [PubMed]

27. Kruse, R.; Ruzicka, T. DNA mismatch repair and the significance of a sebaceous skin tumor for visceral cancer prevention. Trends Mol. Med. 2004, 10, 136-141. [CrossRef]

28. Hall, M.J.; Neumann, C.C.; Lamont, J.T.; Grover, S. Lynch syndrome (hereditary nonpolyposis colorectal cancer): Clinical manifestations and diagnosis. In UpToDate; Post, T.W., Ed.; UpToDate: Waltham, MA, USA, 2020. Available online: https://www. uptodate.com/contents/lynch-syndrome-hereditary-nonpolyposis-colorectal-cancer-clinical-manifestations-and-diagnosis (accessed on 24 May 2021).

29. Everett, J.N.; Raymond, V.M.; Dandapani, M.; Marvin, M.; Kohlmann, W.; Chittenden, A.; Koeppe, E.; Gustafson, S.L.; Else, T.; Fullen, D.R.; et al. Screening for germline mismatch repair mutations following diagnosis of sebaceous neoplasm. JAMA Dermatol. 2014, 150, 1315-1321. [CrossRef]

30. Boennelycke, M.; Thomsen, B.M.; Holck, S. Sebaceous neoplasms and the immunoprofile of mismatch-repair proteins as a screening target for syndromic cases. Pathol. Res. Pract. 2015, 211, 78-82. [CrossRef]

31. Lamba, A.R.; Moore, A.Y.; Moore, T.; Rhees, J.; Arnold, M.A.; Boland, C.R. Defective DNA mismatch repair activity is common in sebaceous neoplasms, and may be an ineffective approach to screen for Lynch syndrome. Fam. Cancer 2015, 14, 259-264. [CrossRef]

32. Kuwabara, K.; Suzuki, O.; Chika, N.; Kumamoto, K.; Minabe, T.; Fukuda, T.; Arai, E.; Tamaru, J.-I.; Akagi, K.; Eguchi, H.; et al. Prevalence and molecular characteristics of DNA mismatch repair protein-deficient sebaceous neoplasms and keratoacanthomas in a Japanese hospital-based population. Jpn. J. Clin. Oncol. 2018, 48, 514-521. [CrossRef]

33. Hatta, N.; Takata, A.; Ishizawa, S.; Niida, Y. Family with MSH2 mutation presenting with keratoacanthoma and precancerous skin lesions. J. Dermatol. 2015, 42, 1087-1090. [CrossRef] [PubMed]

34. Hussein, M.R.; Roggero, E.; Sudilovsky, E.C.; Tuthill, R.J.; Wood, G.S.; Sudilovsky, O. Alterations of mismatch repair protein expression in benign melanocytic nevi, melanocytic dysplastic nevi, and cutaneous malignant melanomas. Am. J. Dermatopathol. 2001, 23, 308-314. [CrossRef] [PubMed]

35. Perrett, C.; Harwood, C.; McGregor, J.; Warwick, J.; Cerio, R.; Karran, P. Expression of DNA mismatch repair proteins and MSH2 polymorphisms in nonmelanoma skin cancers of organ transplant recipients. Br. J. Dermatol. 2009, 162, 732-742. [CrossRef] [PubMed]

36. Eiberg, H.; Hansen, L.; Hansen, C.; Mohr, J.; Teglbjaerg, P.S.; Kjaer, K.W.; Teglbjærg, P.S. Mapping of hereditary trichilemmal cyst(TRICY1)to chromosome 3p24-p21.2 and exclusion of $\beta$-CATENIN and MLH1. Am. J. Med. Genet. Part A 2005, 133 A, 44-47. [CrossRef] [PubMed]

37. Cilona, M.; Locatello, L.G.; Novelli, L.; Gallo, O. The mismatch repair system (MMR) in head and neck carcinogenesis and its role in modulating the response to immunotherapy: A critical review. Cancers 2020, 12, 3006. [CrossRef] [PubMed]

38. Reichrath, J.; Rass, K. Ultraviolet Damage, DNA Repair and Vitamin D in Nonmelanoma Skin Cancer and in Malignant Melanoma. Adv. Exp. Med. Biol. 2014, 810, 208-233. [CrossRef]

39. Loureiro, J.B.; Abrantes, M.; Oliveira, P.; Saraiva, L. P53 in skin cancer: From a master player to a privileged target for prevention and therapy. Biochim. Biophys. Acta BBA Rev. Cancer 2020, 1874, 188438. [CrossRef] 
40. Vasan, K.; Anand, S.; Satgunaseelan, L.; Asher, R.; Low, H.; Palme, C.E.; Lee, J.H.; Clark, J.R.; Gupta, R. Mismatch repair protein loss in cutaneous head and neck squamous cell carcinoma. J. Surg. Oncol. 2020, 122, 1755-1760. [CrossRef]

41. El Hassani, Y.; Beaulieu, J.-Y.; Tschanz, E.; Marcheix, P.-S. Localisation inhabituelle pulpaire d'un kyste trichilemmal proliférant. Chir. Main 2013, 32, 117-119. [CrossRef]

42. Makiese, O.; Chibbaro, S.; Hamdi, S.; Mirone, G.; George, B. Huge proliferating trichilemmal tumors of the scalp: Report of six cases. Plast. Reconstr. Surg. 2010, 126, 18e-19e. [CrossRef] [PubMed]

43. López-Ríos, F.; Rodríguez-Peralto, J.L.; Aguilar, A.; Hernández, L.; Gallego, M. Proliferating trichilemmal cyst with focal invasion. Am. J. Dermatopathol. 2000, 22, 183-187. [CrossRef] [PubMed]

44. Erdem, H.; Uzunlar, A.K.; Ozcelik, D.; Yildirim, U.; Sahiner, C.; Toplu, G. Posttraumatic giant proliferating trichilemmal cysts on the parietal region of the scalp. Indian J. Dermatol. Venereol. Leprol. 2011, 77, 707-709. [CrossRef]

45. Al-Shanawani, B.; Abdelhamid, M.M.; Al-Shomer, F.M. Giant proliferating trichilemmal tumor. Arch. Plast. Surg. 2013, 40, 461-463. [CrossRef] [PubMed]

46. Mohamed, M.; Soua, Y. Giant proliferating trichilemmal cyst. Pan Afr. Med. J. 2014, 18, 195. [CrossRef] [PubMed]

47. Challita, R.; Halabi, S. Giant aggressive forehead tumor: A 15-year follow-up. Clin. Pract. 2019, 9, 1172. [CrossRef]

48. Fuchs, E. Scratching the surface of skin development. Nature 2007, 445, 834-842. [CrossRef] [PubMed]

49. Zhang, H.; Zhao, H.; Qiao, J.; Zhang, S.; Liu, S.; Li, N.; Lei, X.; Ning, L.; Cao, Y.; Duan, E. Expansion of hair follicle stem cells sticking to isolated sebaceous glands to generate in vivo epidermal structures. Cell Transplant. 2016, 25, 2071-2082. [CrossRef] [PubMed]

50. Sakamoto, F.; Ito, M.; Nakamura, A.; Sato, Y. Proliferating trichilemmal cyst with apocrine-acrosyringeal and sebaceous differentiation. J. Cutan. Pathol. 1991, 18, 137-141. [CrossRef]

51. Dekio, S.; Imaoka, C.; Jidoi, J. Proliferating trichilemmal tumor with apocrine sweat glands. J. Dermatol. 1990, 17, $391-393$. [CrossRef] [PubMed]

52. Lindsey, S.F.; Aickara, D.; Price, A.; Pavlis, J.; Elgart, G.; Cho-Vega, J.H.; Wei, E.X. Giant proliferating trichilemmal cyst arising from a nevus sebaceus growing for 30 years. J. Cutan. Pathol. 2017, 44, 639-642. [CrossRef]

53. Shen, Y.; Zhang, S.; Huang, X.; Chen, K.; Shen, J.; Wang, Z. Involvement of p53 mutation and mismatch repair proteins dysregulation in NNK-induced malignant transformation of human bronchial epithelial cells. BioMed Res. Int. 2014, 2014 , 920275. [CrossRef] [PubMed]

54. Lin, X.; Ramamurthi, K.; Mishima, M.; Kondo, A.; Christen, R.D.; Howell, S.B. P53 modulates the effect of loss of DNA mis-match repair on the sensitivity of human colon cancer cells to the cytotoxic and and mutagenic effects of cisplatin. Cancer Res. 2001, 61, 1508-1516.

55. Liang, S.B.; Furihata, M.; Takeuchi, T.; Sonobe, H.; Ohtsuki, Y. Reduced human mismatch repair protein expression in the development of precancerous skin lesions to squamous cell carcinoma. Virchows Arch. 2001, 439, 622-627. [CrossRef]

56. Ciavattini, A.; Piccioni, M.; Tranquilli, A.L.; Filosa, A.; Pieramici, T.; Goteri, G. Immunohistochemical expression of DNA mismatch repair (MMR) system proteins (hMLH1, hMSH2) in cervical preinvasive and invasive lesions. Pathol. Res. Pract. 2005, 201, 21-25. [CrossRef]

57. Young, L.; Listgarten, J.; Trotter, M.; Andrew, S.; Tron, V.A. Evidence that dysregulated DNA mismatch repair characterizes human nonmelanoma skin cancer. Br. J. Dermatol. 2007, 158, 59-69. [CrossRef] [PubMed]

58. Singh, R.S.; Grayson, W.; Redston, M.; Diwan, A.H.; Warneke, C.L.; McKee, P.H.; Lev, D.; Lyle, S.; Calonje, E.; Lazar, A.J.F. Site and tumor type predicts DNA mismatch repair status in cutaneous sebaceous neoplasia. Am. J. Surg. Pathol. 2008, 32, 936-942. [CrossRef]

59. North, J.P.; Golovato, J.; Vaske, C.J.; Sanborn, J.Z.; Nguyen, A.; Wu, W.; Goode, B.; Stevers, M.; McMullen, K.; White, B.E.P.; et al. Cell of origin and mutation pattern define three clinically distinct classes of sebaceous carcinoma. Nat. Commun. 2018, 9, 1894. [CrossRef] [PubMed]

60. Campos, M.A.; Macedo, S.; Fernandes, M.S.; Pestana, A.; Pardal, J.; Batista, R.; Vinagre, J.; Sanches, A.; Baptista, A.; Lopes, J.M.; et al. Prognostic significance of RAS mutations and P53 expression in cutaneous squamous cell carcinomas. Genes 2020, 11, 751. [CrossRef]

61. Hwang, L.-A.; Phang, B.H.; Liew, O.W.; Iqbal, J.; Koh, X.H.; Koh, X.Y.; Othman, R.; Xue, Y.; Richards, A.M.; Lane, D.P.; et al. Monoclonal antibodies against specific p53 hotspot mutants as potential tools for precision medicine. Cell Rep. 2018, 22, $299-312$. [CrossRef]

62. Shi, Y.; Norberg, E.; Vakifahmetoglu-Norberg, H. Mutant p53 as a regulator and target of autophagy. Front. Oncol. 2021, 10, 607149. [CrossRef] [PubMed]

63. Boeckmann, L.; Martens, M.C.; Emmert, S. Molecular biology of basal and squamous cell carcinomas. Adv. Exp. Med. Biol. 2020, 1268, 171-191. [CrossRef] [PubMed]

64. Bakshi, A.; Shafi, R.; Nelson, J.; Cantrell, W.; Subhadarshani, S.; Andea, A.; Athar, M.; Elmets, C. The clinical course of actinic keratosis correlates with underlying molecular mechanisms. Br. J. Dermatol. 2019, 182, 995-1002. [CrossRef]

65. Javor, S.; Gasparini, G.; Biatta, C.M.; Cozzani, E.; Cabiddu, F.; Ravetti, J.L.; Vellone, V.G.; Parodi, A. P53 staining index and zonal staining patterns in actinic keratoses. Arch. Dermatol. Res. 2021, 313, 275-279. [CrossRef] [PubMed]

66. Reichrath, J.; Reichrath, S.; Vogt, T.; Römer, K. Crosstalk between vitamin D and p53 signaling in cancer: An update. Adv. Exp. Med. Biol. 2020, 1268, 307-318. [CrossRef] 
67. Berman, B.; Cockerell, C.J. Pathobiology of actinic keratosis: Ultraviolet-dependent keratinocyte proliferation. J. Am. Acad. Dermatol. 2013, 68, S10-S19. [CrossRef] [PubMed]

68. Murnyák, B.; Hortobágyi, T. Immunohistochemical correlates of TP53 somatic mutations in cancer. Oncotarget 2016, 7, 64910-64920. [CrossRef]

69. Niyaz, M.; Ainiwaer, J.; Abudureheman, A.; Zhang, L.; Sheyhidin, I.; Turhong, A.; Cai, R.; Hou, Z.; Awut, E. Association between TP53 gene deletion and protein expression in esophageal squamous cell carcinoma and its prognostic significance. Oncol. Lett. 2020, 20, 1855-1865. [CrossRef]

70. McGraw, K.L.; Nguyen, J.; Komrokji, R.S.; Sallman, D.; Al Ali, N.H.; Padron, E.; Lancet, J.E.; Moscinski, L.C.; List, A.F.; Zhang, L. Immunohistochemical pattern of p53 is a measure of TP53 mutation burden and adverse clinical outcome in myelodysplastic syndromes and secondary acute myeloid leukemia. Haematologica 2016, 101, e320-e323. [CrossRef]

71. Chang, H.; Yeung, J.; Qi, C.; Xu, W. Aberrant nuclear p53 protein expression detected by immunohistochemistry is associated with hemizygous P53 deletion and poor survival for multiple myeloma. Br. J. Haematol. 2007, 138, 324-329. [CrossRef]

72. Chen, M.-H.; Qi, C.X.; Saha, M.N.; Chang, H. p53 Nuclear Expression Correlates with Hemizygous TP53 Deletion and Predicts an Adverse Outcome for Patients with Relapsed/Refractory Multiple Myeloma Treated with Lenalidomide. Am. J. Clin. Pathol. 2012, 137, 208-212. [CrossRef] [PubMed]

73. Flynt, E.; Bisht, K.; Sridharan, V.; Ortiz, M.; Towfic, F.; Thakurta, A. Prognosis, Biology, and Targeting of TP53 Dysregulation in Multiple Myeloma. Cells 2020, 9, 287. [CrossRef] [PubMed]

74. Zetner, D.B.; Bisgaard, M.L. Familial Colorectal Cancer Type X. Curr. Genom. 2017, 18, 341-359. [CrossRef] [PubMed] 